ISSN: 2224-0616

Int. J . Agril. Res. Innov. \& Tech. 5(1): 36-39, J une, 2015

Available online at http://www.ijarit.webs.com

\title{
EFFECTS OF BRINING PROCESS ON NUTRIENT COMPOSITION OF FISH SPECIES (KHARO, GOVAZIM AND KIJAR) FROM IRAN
}

\author{
Ali Aberoumand* and Saeed Ziaei-Nejad \\ Received 28 April 2015, Revised 21 May 2015, Accepted 26 June 2015, Published online 30 June 2015
}

\begin{abstract}
This research work was directed on the study of the proximate chemical composition to compare the effect of the brining constant concentration and different times on the nutritive value of fish. The proximate composition of treated Chirocentrus nudus (protein, fat, ash and energetic value) for $8 \%$ salt and $18 \mathrm{~h}$ brining was $61.2 \%, 15.2 \%, 23.2 \%$ and $381.60 \mathrm{kcal} / 100 \mathrm{~g}$ respectively. Fat and ash contents in brined fillets of Nemipterus japonicus and Saurida tumbil were found lower and more than C. nudus respectively. As for the proximate composition of $\mathrm{C}$. nudus, it is clearly observed that all the studied parameters are significantly different in fresh and treated samples. Variations appeared in nutrients was due to the interaction of the salting treatment. It is concluded that fish treated C. nudus was best option.
\end{abstract}

Keywords: Proximate, Fish, Chemical Composition, Salt

Department of Fisheries, Behbahan Khatam Alanbia University of Technology, Behbahan, Iran

*Corresponding author's email: aberoumandali@yahoo.com (Ali Aberoumand)

\section{Introduction}

Fish are important food resources worldwide due to their nutritional quality. Spoilage affects the odor, flavor, texture, color and chemical composition of fish (Agbabiaka et al., 2012) and these in turn affect the nutritional quality, consumer acceptability and commercial value of fish (Daramola et al., 2007). Fish processing helps to extend the storage life of fish and to give the product a form, which is attractive to consumers (Tawari and Abowei, 2011). However, traditionally processed fish are still subject to many form of loss or spoilage such as microbial spoilage, insect infestation and fragmentation (Abolagba and Nuntah, 2011).

Salting is a traditional method of processing fish in many countries of the world. Its often use in drying the fish removes water and lowers the water activity (water available for the support of microbial growth which causes the spoilage) if fish is placed in a solution of salt (brine) stronger than that in the tissues, water will pass from the tissues in to the brine until the strength of the two solution is equal. This phenomenon is known as osmosis. As water passes in to the brine salt will pass in to the tissues. Concentration of $6-10 \%$ salt in the tissues will prevent the action of most spoilage bacteria (Glucas and Ward, 1996). Common salt (NaCl) hinders the activity of bacteria, enzymes and chemicals in fish (Abolagba and Nuntah, 2011). Water is necessary for the microbial and enzymatic reaction involved in spoilage. Salt and vinegar preserve food by reducing the water in them.
The brine salting has obtained popularity in the fish industry. The method that is generally used is as follows: the fish is immersed for 1-4 days in a solution of salt, with salt concentration is $17 \%$ $\mathrm{NaCl}$; removal from the brine; the fillets are placed with thin layers of salt, into stacks, around $1 \mathrm{~m}$ high or in plastic tubs where the stacks are only 30-40 cm high; the fish is then kept stacked for 10-14 days for dry salting after which it is packed. Individual fish may be rotated during storage to even out the pressure exerted on each fish. The main difference between the $1 \mathrm{~m}$ high kench and the $30-40 \mathrm{~cm}$ stacks is the pressure applied to the fish in the bottom layers. Many factors are observed to affect the quality of the final product, including the conditions of the raw material, the type, quality and concentration of salt as well as the salting method (Zaitsev et al., 1969; Beraquet et al., 1983). The salting method has an effect on the structural properties of the fish muscle. When the fish is immersed with brine the rate of salt penetration into the fish muscle is higher than that obtained by dry salting (Akse et al., 1993). It is also observed to provide both better quality and higher weight yield (Beraquet et al., 1983). The concentration of salt in the brine affects the rate of salt diffusion into the muscle and the quantity of water and proteins extracted. The rates of the salt and water diffusion were correlated with increasing salt concentration of the brine (Poernomo et al., 1992; Lawrie, 1998). Protein extraction from the muscle has been shown to be a function of the salt concentration, with a maximum at $6-9 \% \mathrm{NaCl}$. Lower quantities were extracted by pure water or with brine of a higher salt concentration (Lawrie, 
1998). This is clearly an effect of salt/ water on the inter and intra molecular bonds of the muscle proteins and will affect the structure and denaturation of the proteins and the water holding capacity of the muscle. At lower salt concentrations, the muscle swells but at higher salt concentration, above $9-10 \%$, the proteins may have stronger protein-protein bonds with concomitants shrinkage of the muscle and dehydration (Borgstrom, 1968; Offer and Trinick, 1983; Hamm, 1985; Wilding et al., 1986; Morrissey et al., 1987). The amount of swelling will depend on the salt concentration. Muscle swelling has been found to be at a minimum at approximately physiological ionic strength $(0.1$ $\mathrm{m})$ but the maximum swelling of the muscle and water holding capacity have been observed at $1 \mathrm{~m}$ (5.8\% salt) (Offer and Knight, 1988; Fennema, 1990). Brine salting of fish may offer a better control over the rate of changes of salt and water content in the muscle than other salting methods and thereby increase the weight yield and the overall quality of the salted fish. Quality graders of commercial salted fish have indicated that the appearance of the fish may be related to the salting method with adverse effects on appearance and color if the initial salt concentration has been too high. In traditional brine, salting the brine has a specific initial concentration which decreases during the brining process, because of the salt and water exchange between the fish muscle and the surrounding brine. This study evaluated the effect of salt treatment (brining) on the nutrient composition of dried C. nudus, N. japonicus and S. tumbil.

\section{Materials and Methods}

A total of $9 \mathrm{~kg}$ each fish have about $200-300 \mathrm{~g}$ from fish species with English name: Whitefin wolf-hering, Local name: Kharo, Scientific name: Chirocentrus nudus; English name: Japanese threadfin bream, Local name: Govazim, Scientific name: Nemipterus japonicus and English name: Lizardfish, Local name: Kijar, Scientific name: Saurida tumbil were purchased from Market located at Behbahan, Iran. Fishes were preserved in iced container and transferred to the Food Chemistry Laboratory in Behbahan Technology University. The weights of the fish were measured using standard methods. The fish samples were degutted and washed. They were then divided into two treatment groups' fish fillets each. The control (group A) was not immersed in brine. Group B were divided into three groups separately. The first groups were immersed in constant $8 \%$ brine for $6 \mathrm{~h}$, second group for $12 \mathrm{~h}$ and third group for $18 \mathrm{~h}$ in $20^{\circ} \mathrm{C}$ separately.

\section{Drying process}

The treated fishes were laid on the different racks of an oven. At intervals, the fishes were turned to avoid burns and ensure uniform drying. The door of the oven was properly closed to retain heat and prevent contamination from dust and flies. The drying process took about $10 \mathrm{~h}$. The dried fishes were stored separately in open and airtight containers. Fishes fillets from each group were kept in different airtight plastic closed containers with the open end covered with transparent polythene to prevent them from dust, insects and other pests but allow air in through the sides. They were stored in a freezer until testing.

\section{Proximate analysis}

The dried fish stored in airtight containers were analyzed to determine the crude protein, crude fat and ash content. Proximate analyses were based on standard methods as described by AOAC (2000). Crude protein was determined using the Kjeldahl techniques. Ash content was determined by incinerating $1 \mathrm{~g}$ of sample at $600^{\circ} \mathrm{C}$ overnight.

\section{Statistical analysis}

All determinations were carried out in triplicate and the data subjected to two-way analysis of variance (ANOVA).

\section{Results and Discussion}

The proximate composition of the control, brine treated samples carried out were presented in Tables 1, 2 and 3. Percentage weight loss after drying of fish was $3.96 \%, 26.61 \%$ and $37.83 \%$; $0.19 \%, 0.05 \%$ and $0.05 \% ; 2.49 \%, 0.09 \%$ and $0.99 \% ; 0.04 \%, 0.04 \%$ and $0.25 \%$ for the control, brine treated in brining times $6 \mathrm{~h}, 12 \mathrm{~h}$ and $18 \mathrm{~h}$ for three fish species, respectively.

Table 1. Proximate composition of Chirocentrus nudus fillets at constant brine concentration and various brining times in $20^{\circ} \mathrm{C}$

\begin{tabular}{lcccc}
\hline Brine concentration, \%(w/v) & Control & \multicolumn{3}{c}{ Brining time (h) } \\
\hline Trait & 8 & 6 & 12 & 18 \\
\hline Fat (\%) & $16.8 \mathrm{a}$ & $7.09 \mathrm{~b}$ & $4.21 \mathrm{c}$ & $15.2 \mathrm{~d}$ \\
Protein (\%) & $71.2 \mathrm{a}$ & $63.77 \mathrm{~b}$ & $63 \mathrm{~b}$ & $61.2 \mathrm{c}$ \\
Ash (\%) & $8.04 \mathrm{a}$ & $28.95 \mathrm{~b}$ & $30.3 \mathrm{~b}$ & $23.2 \mathrm{c}$ \\
Moisture (\%) & $3.96 \mathrm{a}$ & $0.19 \mathrm{~b}$ & $2.49 \mathrm{c}$ & $0.04 \mathrm{~b}$ \\
Energetic value (Kcal/100g) & $436 \mathrm{a}$ & $318.89 \mathrm{~b}$ & $289.89 \mathrm{c}$ & $381.60 \mathrm{~d}$ \\
\hline
\end{tabular}

abMeans within each response with different superscripts are different $(p<0.05)$. Brining concentration did not affect response $(\mathrm{p}>0.05)$. All data were determined as dried materials. 
Table 2. Proximate composition of Nemipterus japonicus fillets at constant brine concentration and various brining times in $20^{\circ} \mathrm{C}$

\begin{tabular}{lcccc}
\hline Brine concentration, \%(w/v) & Control & \multicolumn{3}{c}{ Brining time (h) } \\
\hline Trait & 8 & 6 & 12 & 18 \\
\hline Fat (\%) & $12.8^{\mathrm{a}}$ & $7.50^{\mathrm{b}}$ & $4.99^{\mathrm{c}}$ & $5.84^{\mathrm{d}}$ \\
Protein (\%) & $57.36^{\mathrm{a}}$ & $63.02^{\mathrm{b}}$ & $61.19^{\mathrm{c}}$ & $63.08^{\mathrm{b}}$ \\
Ash (\%) & $3.29^{\mathrm{a}}$ & $29.43^{\mathrm{b}}$ & $33.73^{\mathrm{b}}$ & $31.04^{\mathrm{b}}$ \\
Moisture (\%) & $26.61^{\mathrm{a}}$ & $0.05^{\mathrm{b}}$ & $0.09^{\mathrm{b}}$ & $0.04^{\mathrm{b}}$ \\
Energetic value (Kcal/100g) & $344.64^{\mathrm{a}}$ & $319.58^{\mathrm{b}}$ & $288.95^{\mathrm{c}}$ & $304.88^{\mathrm{d}}$ \\
\hline
\end{tabular}

ab Means within each response with different superscripts are different $(\mathrm{p}<0.05)$. Brining concentration did not affect response $(p>0.05)$. All data were determined as dried materials.

Table 3. Proximate composition of Saurida tumbil fillets at constant brine concentration and various brining times in $20^{\circ} \mathrm{C}$

\begin{tabular}{lcccc}
\hline Brine concentration, \%(w/v) & Control & \multicolumn{3}{c}{ Brining time (h) } \\
\hline Trait & 8 & 6 & 12 & 18 \\
\hline Fat (\%) & $5.88^{\mathrm{a}}$ & $9.17^{\mathrm{b}}$ & $4.30^{\mathrm{c}}$ & $5.11^{\mathrm{a}}$ \\
Protein (\%) & $52.88^{\mathrm{a}}$ & $60.76^{\mathrm{b}}$ & $66.79^{\mathrm{c}}$ & $60.55^{\mathrm{b}}$ \\
Ash (\%) & $3.41^{\mathrm{a}}$ & $30.02^{\mathrm{b}}$ & $27.92^{\mathrm{c}}$ & $34.09^{\mathrm{d}}$ \\
Moisture (\%) & $37.83^{\mathrm{a}}$ & $0.05^{\mathrm{b}}$ & $0.99^{\mathrm{b}}$ & $0.25^{\mathrm{b}}$ \\
Energetic value (Kcal/100g) & $264.44^{\mathrm{a}}$ & $325.57^{\mathrm{b}}$ & $305.86^{\mathrm{c}}$ & $288.19^{\mathrm{d}}$ \\
\hline
\end{tabular}

ab Means within each response with different superscripts are different $(\mathrm{p}<0.05)$. Brining concentration did not affect response ( $p>0.05)$. All data were determined as dried materials.

The proximate analysis revealed that the crude protein, fat and ash content of dried C. nudus not immersed in brine were significantly $(\mathrm{P}<0.05)$ higher than the brine treated dried C. nudus. The proximate compositions of dried C. nudus, after brining were also significantly different $(\mathrm{P}<0.05)$ from the proximate compositions of dried C. nudus before treating. The ash content of all the groups increased with storage in salt solution. The crude protein of the control was with storage from $71.2 \%$ to $52.88 \%$, which of the brine treated, dried fish reduced from $61.20 \%$ to $60.55 \%$. However, though the fat content of the brine treated, dried fish reduced with storage.

The higher protein and fat contents of the control may be attributed to the fact that they were not subjected to any treatment. Bligh et al. (1988) reported that salting exerts an osmotic effect on fish flesh and as such oil and other constituents may be lost from fatty fish. Sometime protein and fat may have diffused out of the fish during immersion in brine accounting for the lower protein and fat contents of the brine treated fish. The protein contents were higher than the value of $53.10 \%$ recorded by Ogbonna and Ibrahim (2009) and slightly lower than $68.17 \%$ reported by Agbabiaka et al. (2012). The significant differences of proximate composition observed after storage in salt solution may be because of loss during process. The reduction of the crude protein of the stored fish could be due to degradation of the initial crude protein and leaching. The increased ash content of all the groups with storage is in agreement with the findings of Daramola et al. (2007). The proximate analysis of fish stored in baskets was not carried out, as they were unfit for consumption because of the growth of fungi. It is not advisable to eat such fish as they may be affected with mycotoxin and may have some health implications (Hanson and Barlow, 2001; Daramola et al., 2007). The attractive appearances of the control and brine treated dried fish demonstrates one of the benefits of processing. The result showed that storage of properly dried fish in airtight containers delays or prevents altogether the infection of fish by fungi and insects. Fungi infection were worse in brine treated fish in baskets and only affected brine treated fish in airtight containers, this may mean that salt also influences the infection of fungi. These results are in variance with other reports that salting of fish increases the shelf life of fish (Hanson and Barlow, 2001). Bligh et al. (1988) reported that dried salted fish products are susceptible to oxidative changes. Furthermore, they stated that at lower concentrations, salt is a pro-oxidant in fatty species and may inhibit lipid oxidation only at high concentrations.

\section{Conclusion}

The results obtained showed that salt treatment may affect the nutrient composition of C. nudus, N. japonicas and S. tumbil and do not necessarily contribute to extending the shelf life of them. Higher level of salt may be required in the preservation of fatty fish like fish species but consumption of high levels of salt also have some health implications. Increase in ash contents of treated three fish species was duo to remove water from samples and penetration of salt to fish fillets. 


\section{Acknowledgements}

This study financially was supported by the research grants provided by the Behbahan Technology University. Author wish to thank Behbahan Technology University for provide facilities.

\section{References}

Abolagba, O.J. and Nuntah, J.N. 2011. Survey on cured fish processing, packaging, distribution and marketing in Edo and Delta state. Int. Res. Biotech. 2(5): 103-113.

Agbabiaka, L.A., Eke, L.O., Nwankwo, F.C. and Ojuannaiye, A.S. 2012. Efficiency of brine on the nutrient and keeping qualities of smoked catfish (Clarias gariepinus). Int. J. Curr. Res. 4(5): 57-59.

Akse, L., Gundersen, B., Lauritzen, K., Ofstad, R. and Solberg, T. 1993. Saltfisk: Salt modning, Utproving av Analysemetoder, Misfarget Salt fisk (in Norwegian). Tromso: Fiskeri for skning. pp. 1-61.

AOAC. 2000. Official Methods of Analysis. 13th Edn., Association of Official Analytical Chemists, Washington, DC., U.S.A. 684 p.

Beraquet, N.J., Iaderoza, M., Jardim, D.C.P. and Lindo, M.K.K. 1983. Salting of mackerel (Scomber japoonicus) II. Comparison between brining and mixed salting in relation to quality and salt uptake. Coletaneado Instituto de Tecnologia de Alimentos 13: 175- 198.

Bligh, E.G., Shaw, S.J. and Woyewoda, A.D. 1988. Effects of drying and smoking on lipids of fish. In: J.R. Burt (Ed.), Fish smoking and drying: the effect of smoking and drying on the nutritional properties of fish, Aberdeen, UK. pp. 41-52.

Borgstrom, G. 1968. Principles of Food Science. Vol. 1. London: The Macmillan Company, Collier-Macmillan Limited. pp. 285- 313.

Daramola, J.A., Fasakin, E.A. and Adeparusi, E.O. 2007. Changes in physicochemical and sensory characteristics of smoke-dried fish species stored at ambient temperature. Afr. J.Food Agric. Nutr. Dev. 7(6): 169-183.

Fennema, O.R. 1990. Comparative water holding properties of various muscle foods. A critical review relating to definitions, methods of measurement, governing factors, comparative data and mechanistic matters. J. Muscle Foods 1: 363- 381.

Glucas, I.J. and Ward, A.R. 1996. Post-harvest fisheries development: A guide to handling, preservation, processing and quality. NRI, p. 443.

Hamm R. 1985. The effect of water on the quality of meat and meat products: problem and research needs. In: Third internal symposium of properties of water in relation to food quality and stability (edited by J.L. Simatos \& J.L. Multon). Dordrecht, Netherlands: M. Nijhoff Publ. pp. 591-602.

Hanson, S.W. and Barlow, P.J. 2001. Brine treatment, smoking and storage techniques: their effects on the microbial quality of smoked mackerel. The J. Food Tech. Afr. 6(2): 59-62.

Lawrie, R.A. 1998. The storage and preservation of meat II. Moisture control. In: Lawrie's Meat Science, 6th edn. (edited by R.A. Lawrie). Cambridge, UK: Wood head Publishing Limited. pp. 191- 194.

Morrissey, P.A., Mulvihill, D.M. and O'Neill, E.M. 1987. Functional properties of muscle proteins. In: Developments in Food Proteins (edited by B.J.F. Hudson). New York: Elsevier Science. pp.195- 225.

Offer, G. and Trinick, J. 1983. On the mechanism of water-holding in meat: the swelling and shrinking of myofibrils. Meat Sci. 8: 245381.

Offer, G. and Knight, P. 1988. The structural basis of water-holding capacity in meat. Part 1: general principles and water uptake in meat processing. In: R. Lawrie (Ed.). Developments in meat science. New York: Elsevier Applied Science. vol. 4, pp. 61- 171.

Ogbonna, C. and Ibrahim, M.B. 2009. Effect of drying methods on proximate composition of Catfish (Clarias gariepinus). World J. Agric. Sci. 5(1): 114-116.

Poernomo, A., Fawzya, Y.N. and Ariyani, F. 1992. Salting and drying of mackerel. Asian Food J. 7: 141- 146.

Tawari, C.C. and Abowei, J.F.N. 2011. Traditional fish handling and preservation in Nigeria. Asian J. Agric. Sci. 3(6): 427-436.

Wilding, P., Hedges, N. and Lillford, P. 1986. Salt-induced swelling of meat: The effect of storage time, $\mathrm{pH}$, ion-type and concentration. Meat Sci. 18: 55- 75.

Zaitsev, V., Kizevetter, I., Lagunov, L., Makarova, T., Minder, L. and Podsevalov, V. 1969. Saltingand marinating. In: Fish curing and processing. Moscow: MIR Publishers. pp. 198- 256. 